International Journal of Economics, Business and Accounting Research (IJEBAR)

Peer Reviewed - International Journal

Vol-2, Issue-2, 2018 (IJEBAR)

ISSN: 2614-1280, http://www.jurnal.stie-aas/ijebar

\title{
THE EFFECT OF PERFORMANCE AUDITS ON GOVERNMENT APPARATUS ON THE QUALITY OF PUBLIC SERVICES IN BANJARSARI SUB-SUB-DISTRICT SURAKARTA
}

\author{
Maya Widyana Dewi ${ }^{1)}$ Nisa Budianti ${ }^{2)}$ \\ Accounting Study Program STIE-AAS Surakarta, Central Java, Indonesia \\ widyamine77@gmail.com
}

\begin{abstract}
Abstarct
: This study examines the effect of performance audit of the government apparatus on the quality of public services in the Banjarsari sub-sub-district of Surakarta. This research method is descriptive with a qualitative approach. As for the location of the study in Banjarsari sub-district, the research population consisted of 92 people, consisting of the sub-district apparatus and the community in Banjarsari Sub-district. The purpose of this study was to find out (a) the effect of quality audit on work results, audit the quantity of work and audit timeliness on the quality of public services partially; (b) Effect of quality audit on work results, audit quantity of work results and audit timeliness of quality of public services simultaneously; (c) Which performance audit variable is the most influential on the quality of public services in Banjarsari Subdistrict. The data obtained from interviews, collected and processed using the SPSS 23 For Windows Program. The results of the study are (a) quality audit of work results and audit of timeliness have a partial effect on the quality of public services, while auditing the quantity of work is not; (b) quality audit of work results, audit of quantity of work and audit of timeliness simultaneously affect the quality of public services; (c) The most influential performance audit variable is the audit of work quality.
\end{abstract}

Keywords

: Performance Audit, Government Apparatus and Quality of Public Services.

\section{Introduction}

The government is the holder of power, in a democratic state the power comes from the people, to the people and back to the people. Government apparatus that is directly related to the people, namely the sub-district government officials who are often referred to as state servants and public servants. The sub- district government apparatus needs to be equipped with the ability to master science and technology, so that the implementation of services to the community can be achieved as quickly as possible with ease and low cost.

Increased speed depends on the ability of the human resources of the apparatus serving. There are three types of service 


\section{Vol-2, Issue-2, 2018 (IJEBAR)}

ISSN: 2614-1280, http://www.jurnal.stie-aas/ijebar

functions in the district, namely government services, services, development and community services. To determine office employees in providing services, is to use a ratio or each device to provide services to the number of people who provide services.

The Camat Office is a serviceproducing organization or government service that must pay attention to service factors, in order to increase community satisfaction. To improve community satisfaction, a good public service is needed. In this regard, both the government apparatus as servants of the community and the community as government service customers who are served must both comply with the provisions contained in the prevailing laws and regulations.

The good behavior of government officials will have an impact on the quality of public services that are responsible, fair, fast and appropriate. To get a satisfying quality of public services, there is a need for performance evaluations from government officials through performance audits.

Performance audits is an element of assessment in this study to provide contributions and recommendations on the performance of government officials. Linkages to determine the extent of the influence of the performance of the government apparatus on the quality of public services in the District Office.

With the performance audit will be able to resolve various complaints about the low quality of public services. Audit of performance in government apparatus is expected to bring changes to the mindset and work patterns of government officials, especially government officials in Banjarsari District.

Public service institutions that directly face the community, namely Banjarsari Surakarta District. Banjarsari Subdistrict has the main task of holding part of the government's authority delegated from the Mayor to handle part of the regional autonomy affairs. Public services provided by the Surakarta city government to Banjarsari Subdistrict are licensing services which include licensing for making KTP (Resident Identity Card), $K K$ (Family Card), IMB (Building Permit), Not Able Certificate, Moving Letter, Admission Permit, and Disruption Permit .

Performance audit at Banjarsari District government apparatus is expected to bring about a change in a better government, the maximum utilization of technological advances and the existence of government officials who are committed as responsible public servants.

This study focuses on the performance variables of the government apparatus which is seen in 3 (three) aspects / factors, namely the quality of work, quantity of work and timeliness. Furthermore, it will be known that the performance of public government apparatus has been effective or not in its implementation through performance audits.

Based on the description above, it was finally interesting to conduct research with the title "The Effect of Performance Audit on Government Apparatus on the Quality of Public Services in Banjarsari SubDistrict Surakarta". 


\section{Vol-2, Issue-2, 2018 (IJEBAR)}

ISSN: 2614-1280, http://www.jurnal.stie-aas/ijebar

\section{Literature Review}

2.1 Public Sector Audit

Definition of public sector audit according to Rai (2008: 29) is an activity aimed at entities that provide services and supply of goods whose financing comes from tax revenue and other state revenues with the aim of comparing the conditions found with the criteria set. The types of public sector audits include: (a) Financial audits are audits that ensure that the accounting and financial control systems run efficiently and precisely and that financial transactions are authorized and properly recorded, (b) performance audits are systematic checks to obtain and evacuate evidence objectively to be able to independently assess the efficiency of operating performance to be achieved, (c) compliance audit is an audit that checks the expenditures for public services has been approved and in accordance with the applicable law.

\subsection{Performance Audit}

The performance audit focuses the examination on economic actions and events that describe the performance of the entity or the function being audited. Performance audit is a systematic process to obtain and evaluate evidence objectively, so that it can independently assess the economy and operating efficiency, effectiveness in achieving desired outcomes and compliance with applicable policies, regulations and laws, determine the suitability of the performance achieved with predetermined criteria and communicate the results to the users of the report.

2.3 Government Apparatus
Apparatus are people who run the government. The apparatus has a strategic role in carrying out the general tasks of government and development. The role of the apparatus is in accordance with the demands of the times, especially to answer the challenges of the future. Quality apparatus is needed in order to face future challenges.

The understanding of the government apparatus is mentioned by Dharma Setyawan Salam in a book entitled Management of Indonesian Government which explains that "Government Officials are workers who are paid by the government in carrying out technical tasks of government to perform services to the public based on the applicable provisions" (Setyawan, 2004: 169).

Based on the above understanding, the government apparatus is someone who is paid by the government to carry out governmental tasks technically based on the existing provisions.

\subsection{Quality of Public Services}

Quality is a dynamic condition that deals with products, services, people, processes and environments that meet or exceed expectations.

Service is a series of activities that take place routinely and continuously covering the entire life of people in the community (Moenir, 2008: 27).

Public services can be interpreted as providing services (serving) the needs of people or communities who have an interest in the organization in accordance with the basic rules and procedures that have been established (Widodo, 2001: 131). 


\section{Vol-2, Issue-2, 2018 (IJEBAR)}

ISSN: 2614-1280, http://www.jurnal.stie-aas/ijebar

From the above understanding it can be concluded that the quality of public services is a condition in which services bring together or meet or even exceed what consumers expect with the actual performance system of public service providers.

The success of the public service process is very dependent on two parties, namely the bureaucracy (service) and the community (which is served). To see the quality of public services need to be considered and studied two main aspects, namely: First, aspects of the internal process of the bureaucratic organization (servants); Second, the external aspects of the organization are the benefits felt by the customer community. In Kep. Menpan No 63 / KEP/M.PAN/7/2003 concerning General Guidelines for the Implementation of Public Services are classified broadly including administrative services, goods services and services. The purpose of public services (July between 2005; 10) is satisfactory or in accordance with the wishes of the community / customer in general. To achieve this, the quality of service is needed in accordance with the needs and desires of the community. Quality / quality of service is a match between hope and desire with reality. And the essence of public service is the provision of excellent service to the community which is the realization of the obligations of the government apparatus as public servants.

\subsection{Effect of Performance Audit on}

Government Apparatus on the Quality of Public Services

To find out whether the quality of public services is effective or not, it can be seen from several measurement indicators. From these measurement indicators, a performance audit will be carried out, namely: (a) audit of the quality of work, namely the quality that must be produced (whether or not). The qualitative measurement of output reflects the measurement of the level of community satisfaction, (b) auditing the quantity of work, namely the amount that must be achieved or completed. Quantitative measurement involves the calculation of output from the process or implementation of community service activities, (c) audit of timeliness, that is, according to whether or not the planned time is in completing a service.

Through these indicators, it is implied that there is a hope that something better the organization wants to achieve in the future. Thus the goal shows the direction in which performance must be carried out. After a performance audit, will it be seen whether the performance of the government apparatus is more effective or not? More orderly or not? The impact generated after the performance audit will affect the quality of public services which is getting better in order to achieve government goals that are in line with the expectations of the nation.

\section{Research Methodology}

The study was conducted in Banjarsari Subdistrict, Surakarta. The population used in the study consisted of 92 people. Based on the Slovin Formula, the sample of the study found 75 people consisting of 70 people from the community and 5 people from the Banjarsari District government apparatus. 
The source of primary data in this study is that the people who are registered receive services in the District of Banjarsari. The secondary data is a guest book, a book of visits that contains complaints or complaints from the public regarding services in Banjarsari District for 1 (one) month.

Data collection method is done in 2 ways, namely through a questionnaire or questionnaire and documentation. The research variable consists of dependent variables, namely the quality of public services and independent variables, namely audit of the quality of work, quantity of work and timeliness.

\subsection{Research Instruments Test}

a. Validity test

Is an analysis carried out to measure whether the instrument used in the study is truly capable of representing all aspects considered as a conceptual framework. Validity testuses the Pearson product moment correlation test with the help of the SPSS Program. The instrument is said to be valid if the number $r$ counts $>r_{\text {table }}$.

\section{b. Reliability Test}

Reliability test is used to measure that the research instrument is free of misperceptions so as to produce consistent results and can be used in different conditions. Reliability testing uses Cronbach alpha with SPSS program. It is said to be reliable if the Cronbach alpha value > 0.6 (Haryadi Sarjono, Winda Julianita, 2011: 45).

\subsection{Hypothesis Testing Method}

a. Multiple Regression Analysis

Multiple regression analysis is used to determine the effect of independent variables (work quality audit, quantity of work audit and timeliness audit) on the dependent variable (quality of public services in Banjarsari Sub-district Surakarta) jointly and partially.

In this study the multiple regression equation is:

$\mathrm{Y}=\mathrm{a}+\mathrm{b}_{1} \mathrm{X}_{1}+\mathrm{b}_{2} \mathrm{X}_{2}+\mathrm{b}_{3} \mathrm{X}_{3}+\mathrm{e}$

Whereas:

$\mathrm{Y}=$ Public Service Quality Variables

$\mathrm{X}_{1}=$ Working Quality Audit Variables

$\mathrm{X}_{2}=$ Work Quantity Audit Variables

$\mathrm{X}_{3}=$ Timeliness Audit Variables

$\mathrm{a}=$ constant

$\mathrm{b}=$ regression coefficient

$\mathrm{e}=$ error term

b. $\mathrm{t}$ Test

This $t$ test is used to examine the effect of each independent variable (quality audit work, work quantity audit and timeliness audit) on the dependent variable (quality of public services). The steps used are as follows: (a) determine the composition of the hypothesis.

Ho: $\beta 1=0$, there is no significant effect between audit quality of work, audit of the quantity of work and audit of timeliness of the dependent variable (quality of public services) individually.

Ha: $\beta 1=0$, there is a significant influence between the quality audit of work, audit the quantity of work and audit the timeliness of the dependent variable (quality of public services) individually.

b) determine the significant level $\alpha=$ $5 \%$. To find out whether or not $\mathrm{Ho}$ is accepted or rejected, the results of the calculation of significance (sig value) are compared with the level of significance of 0.05 . If the sig value 50.05 then $\mathrm{Ho}$ is 
rejected, which means there is a significant influence of the independent variable on the dependent variable.

If the sig value $>0.05$ means that there is no significant effect of the independent variable on the dependent variable.

\section{c. F Test}

The statistical test $\mathrm{F}$ aims to examine the effect of all independent or independent variables (quality audit work, work quantity audit and timeliness audit) jointly on the dependent or dependent variable (quality of public services). This test is carried out with the SPSS 23. program The testing steps are:

(1) determine the composition of the hypothesis:

Ho: $\beta 1=\beta 2=\beta 3=\beta 4=\beta 5=0$, there is no significant influence between the quality audit of the work, the quantity audit of the work and the audit on the timeliness of the quality of public services together.

Ho: $\beta_{1} \neq \beta_{2} \neq \beta_{3} \neq \beta_{4} \neq \beta_{5} \neq 0$, there is a significant influence between the audit of the quality of work, the audit of the quantity of work and the audit of the timeliness of the quality of public services together.

(2) determine the level of significance $\alpha=$ $5 \%$

To find out whether or not $\mathrm{Ho}$ is accepted or rejected, the results of the calculation of significance (sig value) are compared with the level of significance of 0.05 . If the sig value is $<0.05$, then $\mathrm{Ho}$ is rejected, which means that there is a significant influence of the independent variable on the dependent variable. If the sig value is $>0.05$, it means that there is no significant effect of the independent variable on the dependent variable.

d. Determination Coefficient $\left(\mathrm{R}^{2}\right.$ Test $)$

This test is conducted to find out how much influence the independent variables (quality audit work results, audit the quantity of work and audit timeliness) on the dependent variable (quality of public services).

The coefficient of determination is between 0 and 1 . A small $\mathrm{R}^{2}$ value means that the ability of independent variables is very limited. $R^{2}$ is said to be good if it is getting closer to 1 . (a) If $\mathrm{R} 2$ is equal to 1 it means that the independent variable has a perfect effect on the dependent variable. (b) If $R^{2}$ is equal to 0 , there is no effect of the independent variable on the dependent variable.

\section{Discussion}

As a regional instrument of Surakarta City, Banjarsari District is an element of the regional line whose activities are operational, which provides direct operations to the community. The types of services in Banjarsari Sub-district include making a KTP, Family Card (KK), Certificate of Not Able, Moving Certificate, Building Permit and others which are part of its authority to serve the community.

From various services carried out by Banjarsari District, to evaluate the performance of the government apparatus, a performance audit is needed. Performance audits here are carried out through the first stages, namely questionnaires from the community and from the leaders in the Banjarsari District itself. The results of filling out the 
questionnaire will show how long the performance of the government apparatus in Banjarsari District has been. It is expected that with the evaluation of the performance audit can improve the quality of public services in Banjarsari District.

SPSS calculation results on multiple regression analysis are shown:

$$
\begin{aligned}
& Y=2,671+0,524 X_{1}+0,299 X_{2} \\
& +0,359 X_{3}
\end{aligned}
$$

A constant of 2,671 states that if the apparatus performance in Banjarsari subdistrict does not have an audit of work quality (X1), does not have a work quantity audit (X2) and does not have a timeliness audit (X3), then the service quality is 2,671 . The regression coefficient on the value of each independent variable states that each addition of 1 audit of work quality (X1) will improve the quality of public services by 0.524 . Similarly, the audit of the quantity of work (X2) will improve the quality of public services by 0.299 . Whereas for each addition of 1 timeliness audit (X3) will improve the quality of public services by 0.359 .

From the results of the study it was found that the audit of the quality of work has a significant influence on the quality of public services. Here is in line with the research conducted by Noviyanti Harumi (2014), which means that Banjarsari District with a full sense of responsibility is able to serve the community well, then the performance of the apparatus is realized optimally, ranging from the attitude of the apparatus to the alertness of the apparatus in completing the work.

The results of the audit of the quantity of work have an influence on the quality of public services. Here is in line with research conducted by Roro Rukmiati (2012). This means that in Banjarsari Subdistrict, the volume indicator of the amount of work produced is in accordance with the applicable regulations. Audit of the quantity of work is inseparable from the minimum service standards both in terms of physical, the number of apparatus that provide services, and the number of adequate infrastructure.

Furthermore, the timeliness audit also has a significant influence on the quality of public servants. This result is also in line with the research conducted by Eurika Wulan Sasti (2015), timeliness required discipline of the apparatus in their readiness to provide services quickly and precisely, this indicates that the performance of the government apparatus has added value so as to create excellent service quality.

Furthermore, this study produced the simultaneous effect of the three variables on the quality of public services. The better service performed both from attitudes, facilities and infrastructure that are increasingly adequate and the management of the right performance time will have a good impact on improving the quality of public services by Banjarsari District officials. It is expected that by conducting a performance audit on the government apparatus in Banjarsari District will continue to bring progress towards a better one.

From the results of the determination coefficient test, the value of Adjusted $\mathrm{R}$ square is 0.510 . This means that $51 \%$ of the quality of public services can be explained by the quality audit results of the 
work, the audit of the quantity of work and the audit of timeliness. While the remaining $49 \%$ is explained by other variables that were not present in this study.

\section{Conclusion}

Based on the results of the data analysis and the discussion carried out in the previous section, this study yields the following conclusions:

a. Audit of work quality is partially positive effect on the quality of public services in Banjarsari Subdistrict, Surakarta. This is evidenced by the value of $t$ arithmetic (4.039) is greater than $t$ table (1.996) and the level of significance $\mathrm{t}(0.000)$ is less than $\alpha$ (0.05). This means that Ho is rejected and $\mathrm{Ha}$ is accepted where there is a significant influence on audit quality variables on the quality of work on the quality of public services in Banjarsari Subdistrict, Surakarta.

b. Auditing the quantity of work partially has a positive effect on the quality of public services in the District of Banjarsari Surakarta. This is evidenced by the value of $t$ count (2.192) is greater than t table (1.996) and the significance level $t(0.032)$ is less than $\alpha(0.05)$. This means that Ho is rejected and $\mathrm{Ha}$ is accepted where there is a significant influence on the quantity of audit variables on the results of work on the quality of public services in Banjarsari Subdistrict, Surakarta.

c. Audit of timeliness partially has a positive effect on the quality of public services in Banjarsari Subdistrict,
Surakarta. This is evidenced by the value of $t$ count (2.724) is greater than $t$ table (1.996) and the significance level $\mathrm{t}(0.008)$ is less than $\alpha(0.05)$. This means that Ho is rejected and $\mathrm{Ha}$ is accepted where there is a significant influence of audit variables on the timeliness of the quality of public services in Banjarsari Sub-district, Surakarta.

d. Audit the quality of work, audit the quantity of work and audit timeliness simultaneously affect the quality of public services in the District Banjarsari Surakarta. This is evidenced by the calculated $\mathrm{F}$ result $(26,623)$ greater than $\mathrm{F}$ table $(2,731)$ at $5 \%$ error level and based on numerator $(\mathrm{k})=3$ and denominator $(\mathrm{nk})=72$. This means that Ho is rejected where there is a significant influence between haisl quality audit work variables, work quantity audit and audit timeliness together on the quality of public services in Banjarsari Sub-district Surakarta.

\section{Recommendation}

a. It is expected that the provision of quality of service to the community carried out by the Banjarsari District apparatus pay more attention to the level of work accuracy, work neatness and work hygiene, even though the results of quality research work are enough to contribute or influence the quality of service.

b. It is better for the Banjarsari District officials to be better able to utilize computer operations and be able to produce data that is appropriate to the 
International Journal of Economics, Business and Accounting Research (IJEBAR)

Peer Reviewed - International Journal

Vol-2, Issue-2, 2018 (IJEBAR)

ISSN: 2614-1280, http://www.jurnal.stie-aas/ijebar

needs of the community. All services available are in accordance with the rules that have been agreed upon by taking into account the timeliness of carrying out public services.

c. In the future, a more thorough audit of these public services should be carried out, and carried out by more professional staff so that more improvements can be made if there are obstacles.

d. It is expected to enable the use of suggestion boxes located in Banjarsari Subdistrict so that the community can continuously respond to the services provided so that improvements can be made more quickly.

\section{References}

Andayani, Wuryan. 2007. Akuntansi Sektor Publik. Malang: Banyumedia

Halim, Abdul. 2002. Akuntansi Sektor Publik: Akuntansi Keuangan Daerah. Jakarta: Salemba Empa

Hardiansyah. 2011. Kualitas Pelayanan Publik. Yogyakarta: Gaya Media

Harumi, Noviyanti. 2014. Pengaruh kinerja pegawai terhadap kualitas pelayanan publik di PDAM Tirtanadi cabang Sei Agul

Hasibuan, Malayu SP. 2003. Manajemen Sumber Daya Manusia. Jakarta: Bumi Aksara

Kasmir, 2005. Etika customer service. Jakarta: Penerbit PT. Raja Grafindo persada

Mahmudi. 2005. Manajemen Sektor Publik. LPP. AMP. YKPN. Yogyakarta

Mardiasmo. 2009. Akuntansi Sektor Publik. Yogyakarta: Penerbit Andi
Priyatno, Duwi. 2008. Mandiri Belajar SPSS. Cetakan Ketiga, Yogyakarta: Media Kom

Rai, I Gusti Agung. 2004. Audit Kinerja Pada Sektor Publik. Jakarta: Salemba Empat

Rukmiati, Roro. 2012. Pengaruh kinerja aparatur pemerintah terhadap kualitas pelayana publik di Kecamatan Banjarbaru.

Sugiono. 2007. Metode Penelitian Bisnis. Bandung: CV. Alfabeta

Tangkilisan, Heser Nogi S. 2005. Manajemen Publik. Jakarta: PT. Gramedia Widiasarana

Tjiptono, Fandy. 2004. Kepuasan Dalam Pelayanan. Jakarta: Salemba Empat

Widodo, joko. 2001. Good Governance, Telaah dari Dimensi Akuntabilitas dan Kontrol Birokrasi Pada Era Desentralisasi dan Otonomi Daerah. Surabaya: Insan Cendikia

Wulan Sasti, Eurika. 2015. Pengaruh kinerja pegawai terhadap pelayanan publik pada Kantor Camat Kondur

Keputusan Menteri Pendayagunaan Aparatur Negara Nomor 81 Tahun 1993 tentang Pedoman Tatalaksana Pelayanan Umum

Keputusan Menteri Pendayagunaan Aparatur Negara Nomor 16 Tahun 2014 tentang Pedoman Survei Kepuasan Masyarakat

Peraturan Pemerintah No 19 ahun 2008 Tentang Kecamatan

Undang-Undang Republik Indonesia No 32 Tahun 2004. Tentang Pemerintahan Daerah. Jakarta: Sinar Grafika 
International Journal of Economics, Business and Accounting Research (IJEBAR)

Peer Reviewed - International Journal

Vol-2, Issue-2, 2018 (IJEBAR)

ISSN: 2614-1280, http://www.jurnal.stie-aas/ijebar

http://www.landasanteori.comm/2015/10/p engertian-kualitas-pelayananpublik.html

https://www.kamusbesar.com/aparaturpemerintah

http://www.pengertianmenurutparaahli.net/ pengertian-aparatur/

http://makassar.lan.go.id/index.php/survei/ publikasi/artikel/456-aparat-negaraatau-aparat-pemerintah-dalamframe-pelayanan-publik-muskamals-sos-m-si

http://www.psychologymania.com/2012/1 2/pengertian-kualitas-pelayananpublik.html 